Historic, Archive Document

Do not assume content reflects current scientific knowledge, policies, or practices. 



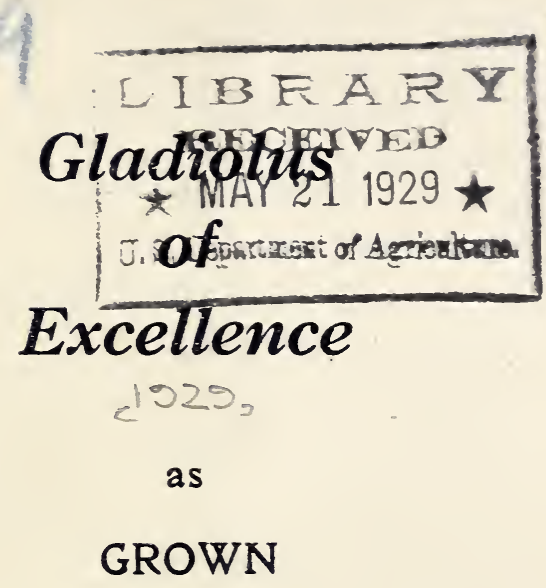

by

Gladrock

6

Gardens

79 Wood Ave., Mattapan, Mass.

RAYMOND S. CLARK, PROP.

TELEPHONE HYDE PARK 1712-M

M EMBER OF A. G. S. \& N. E. G.S. 


\section{"GLADROCK" GLADIOLUS}

\section{Choice Varieties for 1929}

\section{Guaranteed True to Name}

Each

Albania. Large clear white...........8c., 2 for $15 \mathrm{c}$ Alice Tiplady. Fine orange saffron Primulinus,

Alma Gluck. Bright peach red, yellow throat $15 \mathrm{c}$.

Black Joe. Fine deep red...................10c.

Bronze Beanty. Colonial buff, overlaid with lines of

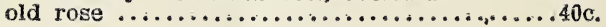

Carmen Sylva. Tall white, slight violet markings

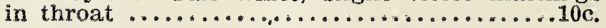

Diana. Fine bright erimson, blooming size, 3 for $10 \mathrm{c}$.

Dr. J. A. Mrills. Tall spike, white with rose pink edges, rose red blotches on lower petals. A beauty ...................................75c.

Dr. Elkins. Showy white with purple blotch....10c. Ethelyn. Tall large flowered orange Prim......25c. Evangeline. Pure white, red markings in throat, $35 \mathrm{c}$. Giant Nymph. Beautiful large rose pink......10c. Gold. Best medium sized pure yellow..........10c.

Golden Measure. Tall, large flowered, clear yel-

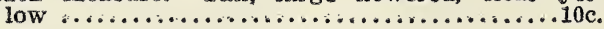

Gov. Hanley. Early bright red..............10c. Halley. One of the earliest, salmon pink.......5c. Helen Todd. Beautiful lavender pink...........10c.

Henry C. Goehl. Fine white, blushed pink with scarlet blotches $\ldots . \ldots, \ldots, \ldots, \ldots, \ldots, \ldots, \ldots, 20$ c,

Herada. Pure mauve, deeper throat markings, 
Each

Jeuny Lind. Soft light salmon, creamy throat. As sweet as her namesake..................

Jewell. Tall clear salmon pink, golden throat..10c. Joe Coleman. Rich, ruffled red.................

Le Marechal Foch, A fine large early pink......5c.

Los Angeles. Fine shell pink. A good propagator. Generally has 2 or 3 spikes..............15c.

Margery Gage. Showy creamy pink, crimson blotch $20 \mathrm{c}$.

Maurice Fuld. One of the largest pure rich pink, small blotch of tyrian rose in white throat..5

Ming Toy. Beautiful buff. Prim.....8c, 2 for $15 \mathrm{c}$.

Miss T. Rose. Large creamy blooms, colored like old fashioned tea rose............15c., 2 for $25 \mathrm{c}$.

Montezuma, Fine, tall suffled red.............10c.

Morning Glory. Tall yellow, red throat markings. An improved Schwaben..................10c.

Mrs. Dr. Torton. A symphony in pink and cream, 10c.

Mrs. Frank Pendicton. Very popular pink with carmine blotch ...........................10c.

Irs. F. C. Peters. Orchid lavender, dark lavender blotch. Late.........................10c.

Mrs. Leon Douglas. Begonia rose, striped with scarlet. One of the largest...............20 c.

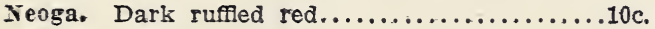

1910 Rose. Light red, lighter midrib on each petal, $8 \mathrm{c} ., 2$ for $15 \mathrm{c}$.

Peace, Large late white, pale lilac throat feathering $\ldots \ldots \ldots \ldots \ldots \ldots \ldots \ldots \ldots, \ldots, \ldots \ldots, 2$ for $15 \mathrm{c}$.

Pink Lily. Beautifu ruffed rose pink........10 c. 
Each

Pink Wonder. Large pure pink.....8c., 2 for $15 \mathrm{c}$. P'rince of India. Fine smoky shades.........20c. Prince of Wales. Early salmon rose, yellow and carmine blotch .......................

Principine. Bright red, white blotch..8c., 2 for $15 \mathrm{c}$. Purple Glory. Dark velvet garnet. A beauty..10c. Rose Mist. Tall spike, rose with gray edging on each petal. One of my favorites..35c., 2 for $60 \mathrm{c}$.

Shaylor, E. J. Early ruffed rose pink. .8c., 2 for $15 \mathrm{c}$. Sovereign. Tall dark violet purple...........25c. Sweet Lavender. Fine early pink lavender.....10c. Sulphur Frills. Ruffled light sulphur yellow. Fine spike .............................25c.

Sunnymede. Distinctive orange, yellow with red blotch. Very fine .....................25c.

Tiffany. One of the best early whites. Slightly ruffied ..............................10c.

Twilight. Creamy buff and pink. Nicely ruffled, $10 \mathrm{c}$. Virginia frale. Beautiful creamy rose, 13c., 2 for $25 \mathrm{c}$.

Violet Beauty. Tall cerise violet, red throat blotches. Fine spike ..................13c., 2 for $25 \mathrm{c}$.

War. Tall late red. Large blooms..8c., 2 for $15 \mathrm{c}$. Wilbrinek. Fine early pink.........7c., 3 for $15 \mathrm{c}$. Choice Mixture. All good ones but not labeled, 50c. per doz.

Garden Mixture. A surprise package...40c., per doz.

Cash with order please. Charges prepaid on orders of $\$ 1.00$ or over. Smaller orders please add 10c. for packing and postage, Send for tulip catalogue in early fall. 12 for price of 10.3 bulbs at dozen rate. 


\section{GENERAL CULTURE}

Plant in any good garden soil in full sunlight if possible. From 3 to 5 inches is the proper depth to plant them and about the same distance apart. Keep ground loosened at all times to keep weeds down and to conserve moisture. In times of drouth, water deeply about once a week. Do not sprinkle. Well rotted manure, sheep manure or a good commercial potato fertilizer helps the growth of the plants. Blooms should be cut in the evening or early morning when the first bloom has opened. Bulbs may be planted from about May 1st to the latter part of June. Bulbs should be dug sometime during October, after the tops begin to turn brown, and before the ground freezes hard. The tops should be cut off an inch or so from the bulb, the bulbs dried a day or two in the open air, then stored in a dry cool place for the winter, where they will not be frozen. Sheep manure, 5c. per lb. 